\title{
The Unintended Gift: The Adventures of Hajii Baba Ispahani as a Transactional Text Between English and Persian Literatures ${ }^{1}$
}

\section{KAMRAN RASTEGAR}

\begin{abstract}
The value of literary translations such as Mīrzā Habìb Iṣfahānì's translation of James Morier's The Adventures of Hajji Baba Ispahani must be understood as determined by the interrelated issues of inter-cultural power dynamics and the construction of literary value in the social contexts of both their origins and their destinations. Thus, we may consider this kind of inter-cultural literary relationship as a form of transaction, with texts and readings measured by both a system of values, and one of costs. This article follows the history of the production of Hajji Baba, through its translation into Persian, and examines its possible value within the social context of the Iranian constitutional revolution. It ends by proposing a possible homophony between the British colonial imaginary and the reformist nationalist discourses foundational to the constitutional revolution, despite the contradictions that remain unresolved with a text that has been accorded high value - if through transaction - within both of these contexts.
\end{abstract}

He announced it as his intention to make a present to us of a certain produce of the earth, unknown in most parts of Asia, but much cultivated in Europe, which would not fail to be of incalculable benefit to the people of Persia; and he requested the vizier to assist him in his undertaking, promising shortly to send him a specimen of the intended gift. (James Justinian Morier, The Adventures of Hajji Baba Ispahani)

\section{Introduction}

The formation and development of literary modernity within a Persian language context is deeply marked on one hand by Iran's colonial experience, written as it is into the fabric of the Qajar era's cultural history, and by the reformist and revolutionary currents culminating in the constitutional revolution of 1906. In addition to the political discourse around constitutionalism, literary activities played no small part in developing the cultural framework of the constitutional movement. ${ }^{2}$ While earlier moments presented a cultural re-imagination of the possible role and structure of literary 
production within a Persian language context - particularly evinced in the body of travel texts produced by 18 th-century and 19th-century Iranian travellers-the two decades before the constitutional revolution coincide with the emergence of fictional narrative as a corollary to the nationalist aspirations encapsulated within the mainstream of the revolution's activists and advocates. An examination of cultural production around the period of the constitutional revolution gives evidence that this was a dynamic period with culturally transformative qualities, even in ways that seem contradictory to later, more official, understandings of it. In the years preceding the revolution, this dynamism is exemplified by the increased literary transactions between different cultural and social contexts. $^{3}$

Translations were one such mechanism of literary transaction, as were travelogues, no less than the publication of exilic periodicals in the India, Istanbul and the Arab world as well as in Europe. Yet the act of textual circulation must be understood as mitigated, to some extent, by the interrelated issues of intercultural power dynamics within a field of interpretation that allows for deliberate appropriations of works against the grain of the intent of the original author or the author's presumed readership. Given this, a circulation of texts can be better understood as a transaction, with texts and readings weighed by both a system of values, and one of costs. This article deploys a mode of analysis based on tracing textual transactions to assess the issue of the circulation of one specific text, The Adventures of Haji Baba Ispahani, through its translation into Persian, with special recourse to the transactional dynamics of the transmission of the text into the social context of the Iranian constitutional revolution. This investigation will begin with an explication of the confusions that surrounded the authorship of the text, particularly where the Persian translation is concerned, a confusion that is telling of the differential values of the text within the British and Iranian contexts, brought to light through the text's circulation between them with an aim to interrogate the paradoxical appropriation of this text for both colonialist-orientalist as well as anti-colonialist revolutionary imaginaries.

\section{Readers, Texts and their Values}

In what follows, I would like to examine how readers are able to actively subvert the verbal cues that would authorize a particular reading of the text. Garrett Stewart, writing of the conscriptive 'Dear Reader' so often stumbled across in the 19th-century British novel, argues persuasively that the textually invocative moment reveals the texts' 'tactic for the annexation of receptive consciousness into subjectivity', which he later calls 'the conscriptive event'. ${ }^{4}$ The move from Althusser's interpellative 'hey, you' to the polite presumptions that belie the 'conscription' of the 'dear' reader's consciousness is, however, a short one that implicates the author - text-reader relationship into a general framework of an apparatus of ideology and its subject. The authority of the text in this relationship, it is true, is clearer to establish than the possible agency of the reader that is raised in my introductory statement. However, there is a place for an accounting of the complicity of readerships - that is to say, a social imagination-as being less predetermined than the call to the 'dear reader' may make it seem. ${ }^{5}$ The exercising of this kind of agency has been called 'deliberate mis-reading' or 'counter-interpellation', and has been given various justifications, including the ignorance of 'incompetent' readerships or the shortcomings of semi-literate readerships. Yet these terms are limiting: mis-reading presumes canonical readings, just as reading competence has an 
ever-shifting measure. Indeed, a translated text may offer a particularly valuable point of entry for an examination of this question, if the argument of the invocative power of the text is made on the basis of a discussion of socially delimited values. Translations, those that cross significant social boundaries, are clearly prime arenas for the engagement of a readership on a basis unrelated to the aura of authorial intention. This article will examine just such a setting; that of a translation that in its birth had an uncertain social value, and that through a variety of interventions was refigured as containing a certain potential for the counter-interpellation of a secondary readership vis-à-vis the originallanguage text.

In early 1824, John Murray, an English publisher, released an anonymously penned volume with the title The Adventures of Hajji Baba of Ispahan. But in some sense, the story of Hajii Baba begins some time before: in 1807, a 24 year old by the name of James Justinian Morier was deployed into the relatively hermetic social sphere of Qajar-era Iran as the private secretary of Harford Jones, the special envoy from King George to the Qajar Fath Ali Shah. By the time of his return to England, Morier had already begun to capitalize on his experiences by writing memoirs of his travels and work, which were released in the two volumes fourney through Persia, Armenia and Asia Minor and Second fourney through Persia. While pleased with the quiet acclaim these works attracted, he then set his sights on the larger market offered by the novel. Thus was the character of 'Hajji Baba of Ispahan' introduced to a British readership.

One British literary historian has remarked that it is not surprising that [Morier] should have decided to exploit his exceptional knowledge of a little-known country'thus confirming the value that a certain knowledge of distant cultures might bear in the market of fiction writing at that time in Britain. Furthermore, the same critic continues, this was 'an age in which novels were so much in demand and there was... [a] keen an interest in the East'. ${ }^{6}$ This interest in the East, borne out in the accumulation of numerous translations and pseudo-translations of Oriental texts, also may have influenced Morier to stretch his facilities from bureaucratic writing and intelligence reportage to the whimsical style he conjures in Hajji Baba. Perhaps the novel, a relatively new and ascendant literary form in the English literary market by the mid-1820s, beckoned too strongly to a middle-aged and sedentary ex-diplomat living somewhat beyond his means. Morier may have come to appreciate the cultural value of literary representations of his experiences in a part of the world that was now a source for the British public's literary fantasies.

Some decades later, perhaps some 30-odd years after Morier's death in 1849, Mīrzā Ḥabỉb Iṣfahānī (183? - 1893), an exiled Iranian man of letters, translator, instructor and author of two books on the grammar of Persian, sat down to put his pen to translating Morier's The Adventures of Hajji Baba of Ispahan into his native tongue. A Persian translation of the book was first published in 1906, and it was even later before it became recognized as a major landmark in the reworking of Persian prose from the previous courtly and highly ornamented style into a written vernacular, a common and widely understandable prose. The timing of the publication of Mīrzā Habỉb's translation may seem to legitimize what was to become its inclusion into the discourses of anticolonialism and reform that were part of the Iranian Constitutional Revolution of 19061911, the set of events culminating from over a half-century or so of social-reform and political-reform agitation that resulted in the establishment of a constitutional monarchy, the first such constitution in the Middle East. 
That Mīrzā Habìb's Hājoji Bāba continues to be read is a result of the coincidence of a variety factors, both literary (or aesthetic) and political. ${ }^{7}$ Sargozasht-e Ha $\bar{a} j \bar{j} i \quad B \bar{a} b \bar{a}-i$ Is fahān $\bar{\imath}$ has been put on lists including Tâlibof's Kitāb-i Ahmad and Marāghihì s Siyāhatnāmihyi Ibrāhìm Bayk, which, as has been discussed, are often considered canonical within the political texts of modern Iranian literature. ${ }^{8}$ Given the fact that $H \bar{a} \bar{j} j \bar{i} B \bar{a} b \bar{a}$ is a translation of a British novel of the Oriental Tale genre, and that Mirzā Habib was never known for overtly political writing on the order of Tâlibof or Marâghihî, one may ask how it was that $H \bar{a} \bar{j} j \bar{i} B \bar{a} b \bar{a}$ came to be integrated into this canon. Indeed, to this day, none of the other numerous translations of this period are endowed with the literary or social value of $H \bar{a} \bar{j} j \bar{i} B \bar{a} b \bar{a}$. How could an orientalist text be read as supporting a nationalist and largely anti-colonial movement such as Iranian constitutionalism? What counter-interpellations signified the move of $H \bar{a} \bar{j} j \bar{i} \mathrm{~B} \bar{a} b \bar{a}$ from orientalist and colonialist to constitutionalist and anti-colonialist imaginations?

As I have suggested above, the crossing of the paths of Morier and Mīrzā Habỉb marks also the intersection of what have been termed fundamentally opposing discourses: colonialist orientalism and nationalist constitutionalism. Later in this paper I will interrogate the connections of Morier to an orientalist discourse, and Mīrzā Habỉb to nationalist constitutionalism, but what is more suspect, perhaps, is the claim of a fundamental opposition of modernist constitutionalism to orientalism. In investigating the cultural economies within which the two versions of the text circulated, this question arises over and over. Is it that Mīrzā Habỉb's very able and literate translation (deemed by many Iranian critics, not surprisingly perhaps, as superior to Morier's original text) 'transformed a colonialist text into an anti-colonialist one', as one Iranian literary historian has put it? ${ }^{9}$ Or, literary 'value' notwithstanding, was there more at play in the transference of an Englishman's attempt at a popular 'oriental tale' into a cultural sphere where, as I will discuss later, $H \bar{a} \bar{a} j \bar{i} B \bar{a} b \bar{a}$ was to be identified with the martyred leaders of the constitutionalist movement?

In attempting to address these questions, this paper will first be centred on the issues of the authorship of Hajji Baba, as they are both historically-and theoreticallyconstituted, to suggest reasons for the misidentification of the translator of Hajji Baba by orientalist scholars, and to understand the implications of this misidentification for later engagements with the text. Then I will examine the character of Hajji Baba and offer readings of the characteristics of this fictive personage within the context of both an orientalist discourse and an aspiring nationalist discourse, and the cultural economies of the readerships of each. Finally, I will discuss the readerships-both imagined and documentable - of these texts, with a specific interest in showing the relationship of the development of a new narrative tradition (and a readership for it) as part of a political and social reform movement, in the Iranian context, to transformations in value of the consumable fantasies of the British novel, affected by the developing colonialist discourses of the 19th century. The question of the reader, presumed readerships, and counter-interpellations of the text by readers will lurk between the lines of these analyses.

\section{Misrecognition and Authorship}

Confusion over the authorship of Hajji Baba was to follow the book for decades after its initial publications, in both the English and Persian versions of the book. In 1824, James Morier contracted with John Murray for the publication of his book-and, as was not uncommon, the book was released with no stated authorial credit. The introduction, a 
clearly satirical letter to one 'Rev. Fundgruben', was signed 'Peregrine Persic', a false editorial moniker, as the book was in its own fictional claim the work of Hajji Baba himself, and was only translated by the former diplomat 'Persic'. The first British review of Hajji Baba, published in Blackwood's Edinburgh Magazine, misidentified the text as a sequel by Thomas Hope to his popular novel, Anastasius, and argued that Hajji Baba was significantly inferior to the latter. ${ }^{10}$ Sir Walter Scott would later step in to rescue the literary reputation of Hajji Baba and its author, repositioning the text and arguing for its placement among the highest productions of the Oriental Tales genre. The debate that Scott was to enter concerned the kind of value Hajji Baba was to be endowed with. Scott describes Hajji Baba as 'a lively and entertaining history of the hero... an easy and humorous introduction... to the oriental manners and custom, but especially to those which are peculiar to the Persians'. ${ }^{11}$ Despite the harsh criticism of Blackwood's Edinburgh Magazine for the book on literary and other counts, what was to emerge from the critiques of the book in the mid-19th to late-19th century is an estimation of an ethnographic value (such as Scott's) of the book, which was to drive any regard for its possible 'literary' value. It is noteworthy that over the course of the mid to late 20th century, British and American literary critics, perhaps uncomfortable with the use of a purely ethnographic reading for assessing the book's ultimate value, have begun to find ways to argue that the book's appeal may be more 'literary' than previously considered, perhaps simply to justify its enduring popularity, even as it continues to be read with an eye to its ethnographic value. ${ }^{12}$

Not only did Hope briefly replace Morier as the identified author of the text, but so was Mīrzā Habìb Iṣfahān̄̄ later to be confused with his friend and associate Shaykh Ahmad Rūḥ̄, whom any reader of E. G. Browne's A Literary History of Persia 1500-1924 would have to conclude to have been the translator of Haji Baba. ${ }^{13}$ Furthermore, a full generation of Iranian literary scholars debated passionately whether or not Morier could have been the author, or whether he himself had taken the glory from an actual 'Hajji Baba' (i.e. taking the introduction of the text to be, albeit satirically phrased, a sort of admission of the truth, which led to an entire area of inquiry that focused on the possible identification of this person). ${ }^{14}$ What can be concluded from these confusions is that the social identification of the authorship of Hajji Baba was for a period of time an issue of confusion in both languages (much longer in the Iranian case). How this confusion impacted the reception of the text in any particular time and social setting requires some delicacy to unravel.

The mis-identifications that have muddied an understanding of the Persian translation of Hajji Baba may have had a large role to play in a certain kind of association it was given to constitutionalism. The origin of this confusion is clearly to some extent Mīrzā Habib's association with the group of Istanbul-based Iranian constitutionalists led by the charismatic Sheikh Ahmad Rūhī Kermān̄̄, who were related to the pan-Islamic ideology of the Muslim modernist revivalist, Sayyid Jamāl al-Dīn al-Afghānī. ${ }^{15}$ These two figures were implicated in the assassination of Nāṣir al-Dīn Shāh in 1896, a fact that led to Shaykh Ahmad's eventual expulsion from Ottoman domains, and his brutal murder by royal agents as he was being transported to Tehran. A few years earlier, Mīrzā Habîb's death was recorded in the Persian-language reformist newspaper, Akhtar, in May 1893. ${ }^{16}$ His obituary emphasizes his distinguished standing within the Iranian intellectual community in Istanbul, stating that in his literary writing in knowledge or erudition he had few peers'. ${ }^{17}$ It is significant that the often-polemical newspaper does not speak of any particular political associations or of a legacy of activism when 
remembering the life of Mīrza Habib. However, it would be incorrect to assume that Mīrzā Habîb was untouched by the political turmoil in Iranian society, or that he was uncommitted in the highly-charged atmosphere of an expatriate community that was at that time central to the fomenting of social discontent. He himself described his flight from Iran as motivated by a personal (but politically tinged) conflict with Muhammad Khan, who was then the commander of the royal bodyguards in Tehran. ${ }^{18}$ His choice to remain in Istanbul for the rest of his years may have been due to continuing intrigues related to the court. ${ }^{19}$ Mìrzā Habỉb, fluent in Arabic, Persian, Turkish and French, apparently had little difficulty employing his erudition to live comfortably under a morehospitable Ottoman government (although, even there, Mīrzā Habīb was expelled from the academy Anjuman-i Ma'arif and from his teaching job for a period, until the Sultan was moved to reinstate him-exactly why, we do not know). ${ }^{20}$ During this time, he is known to have written at least two books on the instruction of Persian, one for use by foreigners and one directed at young Persian-speakers, as well as having published poetry (often in Akhtar), ${ }^{21}$ having edited a book on calligraphy in Turkish, ${ }^{22}$ in addition to producing translations of Gil Blas and plays by Molière. ${ }^{23}$ We may assume that he did other work of this sort, but it does seem as if most of his translation work became publicly known only after his death. Given this biographical information, can it be assumed that his motivation in translating Hajji Baba be either purely 'literary' or 'political' in nature? The scarcity of detail on Mīrzā Habìb's life makes any conjecture that definitively emphasizes one motivation over the other largely irresponsible, but we can see that both are aspects of his life's work and course; and while it is possible that his translation of Hajji Baba was carried out for more 'literary' reasons than not, it certainly was done in such a way and in such a social context so as to make available a 'political' reading of the text.

The 'political' label affixed to the translation of Hajji Baba was initially largely a result of the confusions over its translator's identity. It is perhaps ironic that this confusion was an outcome of the misidentification of the translator by orientalist scholars. The misidentification of Shaykh Aḥmad Rūḥ̄ for Mīrzā Habỉb apparently occurred first in the mind of Major D. C. Phillott, a one-time British counsel in the city of Kerman, who was given a manuscript of the translation of Haji Baba by the associates of Shaykh Ahmad after the latter's murder. Phillott, assuming that the manuscript was Shaykh Ahmad's work, took it with himself to Calcutta after leaving his diplomatic position in 1906 . He oversaw its publication there in Calcutta - not an entirely noteworthy fact, given the presence of a small but active community of Iranian exiles in that part of India, as well as the persistence of an Indian readership of Persian texts even then. However, Phillott's edition is a rather peculiar effort: the book contains an English introduction, and the text is supplemented with a critical apparatus with helpful definitions of certain Persian colloquialisms, in English. The intended audience of this edition is therefore apparently an oddly limited one: perhaps English-speaking students of Persian, or Orientalists for whom the colloquialisms were unfamiliar, or else perhaps Anglophone Indians who wished to increase their knowledge of contemporary Persian. Phillott notes in the introduction that another publisher in Calcutta was at the same time preparing the publication of the same book, and there are references to another Calcutta edition dated 1911. ${ }^{24}$ Sâdeghī reports that another edition was published in Calcutta 'shortly after' Phillott's, by the Habl al-Matīn Press, and edited rather liberally by Mu'ayyid al-Islām Jalāl al-Dīn Husayn̄ - it seems probable that this is the edition Phillott mentions. This second edition was meant for a solely Persian-reading audience, either in India or Iran, 
and thus lacked the additions made by Phillott. Yet even in Iran, later reissues of Hājoì $B \bar{a} b \bar{a}$ were based on the Phillott text and not on the Habl al-Matīn edition. ${ }^{25}$

That Phillott was incorrect in his presumption that Shaykh Ahmad was the translator of Haji Baba is to some extent understandable: the manuscript was, after all, among the possessions of Shaykh Ahmad, and in his own handwriting. What is curious is that Phillott does claim that 'assisted by Mirzâ Habîb, a poet from Ispahan, [Shaykh Ahmad] translated several French and English works, including Haji Baba [sic] and Gil Blas'; and in a footnote to a claim that Shaykh Ahmad had once lived in Isfahan, he concludes 'hence the erroneous idea held by many Persians that the translator [of Hajji Baba] was an Ispahani'. ${ }^{26}$ Clearly, Phillott should have had reasonable cause to think that Mīrzā Habib (the Isfahani) was more than simply 'assisting' Shaykh Ahmad. However, one gets the sense that Phillott is overwhelmed by a need to associate the book with the turmoil, contemporary to his efforts, which was enveloping Iranian society. A reason for the desire of orientalists to politicize this book may be found in an examination of the ambivalence some felt for the constitutional movement. Phillot's introduction for Hājji $B \bar{a} b \bar{a}$ mixes praises for the constitutionalists and bitter lamentations over the brutal death of Shaykh Ahmad with a high esteem for Morier's 'insights' into Iranian societygoing so far as to say that 'Hajji Baba must, in fact, be regarded as serious history and not as burlesque'. ${ }^{27}$ This mixture of a support for constitutionalism mixed with a deeply orientalist perspective on the 'character of this composite people', the Persians, ${ }^{28}$ is one that is present from this very first edition of Mìrza Habib's translation. What is even more curious is the manner in which Phillott blithely characterizes Shaykh Ahad as a Bābī, which he goes on to term an 'obnoxious sect'. ${ }^{29}$ Although Shaykh Ahmad probably had once found the Bābì movement to resonate with his discontentment with the Qajar monarchy, he had clearly disassociated himself from Bābī politics in his later life. ${ }^{30}$ While this is not an entirely appropriate place to discuss the intricacies of Babism and the British opinion of the sect, it is important to understand how un-nuanced Phillott's understanding of the constitutionalists must have been. And the evidence of such misunderstanding is manifold: in his introduction, Phillott goes on to term Jamāl al-Dīn 'Afghānì' 'a Babi leader', an astounding over-statement even if Jamāl al-Dīn did have contacts with Bābī thinkers, which shows a surprising ignorance of either Jamāl al-Dīn's politics, Babism, or probably both. ${ }^{31}$ What emerges is a mind-set in which constitutionalism is interchanged with Babism, which, as an 'obnoxious sect', is a reification of the orientalist perspective of Iran: as if no religio-political movement in Iran could be established on anything but an irrational esotericism, thus Babism metonymically represents the constitutional movement in their mutual antipathy for the Shah. This conflation is quite telling, even if there was a strong influence of Babism on the constitutional movement. The political possibilities of the text, 'proven' through its identification with Shaykh Ahmad, are amplified through the latter's history as an activist. Yet, this political reading of the text must also be substantiated by the thendominant British reading of the text, which viewed Morier's work as a pure documentation of the irrational 'decadence' of the Persians - thus we can understand the collapse of all constitutionalism into Babism. Of course, 1906 also marked the beginning of the constitutional revolution. Phillott's edition was being sent out into a tumultuous social climate, and its introduction clearly identified its publication with the constitutional movements, even as it mis-characterized their leaders.

E. G. Browne also makes mention of the Persian translation of the book in at least two separate volumes on Iranian literature and society. Yet the identity of the translator 
eludes him. Browne would have been the most well-suited individual to establish the identity of Hajji Baba's translator: in July 1892, Browne received a letter from Shaykh Ahmad, as part of a long-standing correspondence between them on literary and political matters. In this letter, after discussing other concerns briefly, Shaykh Ahmad writes:

The admirable literary man, Mîrzâ Habîb Isfahânî has translated the book Hajji $B a b a$ from the French ${ }^{32}$...he wanted to publish the book in Istanbul, but permission was not given by the censor; if you would be agreeable to it, I can send you a copy of the manuscript, and if you would oversee its publication in London, I know of the fact that in Iran a great market and interest exists for it, and Habıb Effendi would give his rights for such a publication. ${ }^{33}$

This note is perhaps the strongest evidence to establish Mīrzā Habîb as the primary and sole translator of the book. However, even after having received this letter from Shaykh Ahmad, Browne went on to cite Phillott's introduction to the Calcutta edition in identifying the translator as Shaykh Ahmad in his 1920 work The History of Persian Literature 1500-1924. Browne also failed to identify Mīrzā Habỉb as the translator in his 1910 text, The Persian Revolution of $1905-1909 .{ }^{34}$ Whether this was a result of a faulty memory, bad notes, or due to a mistrust he felt for Shaykh Ahmad's word (in favour of the opinion of a fellow Englishman) is unclear. However, the latter possibility seems unlikely, given Browne's propensity to cite Iranian and other non-European sources, more so than many of his colleagues. We may only speculate about Browne's motivations in these almost deliberate mis-identifications, and to offer a clear answer we will have to look at Browne's relationship to the constitutionalists a little more closely than the limited scope of this paper will allow. However, while Browne had long been an outspoken supporter of constitutionalist reforms of the Qajars, he was to allay that support somewhat as the populist and anti-colonialist aspects of the revolution were to gain momentum, even as he went on to advocate for the constitutional movement as a whole even years after its collapse. As part of this move, he may have found it more plausible to imagine that a firebrand such as Shaykh Ahmad undertook the translation of Hajji Baba for purely political, polemical reasons, and to repress the potential of a literary man such as Mīrzā Habỉb having had more complex motivations for the translation of the text. The difference would purely be in the nuance that the authorial aura produces. However, for Browne, reading the translation of Hajji Baba as primarily the product of Shaykh Ahmad's politics would simplify the question of its audience, drawing into harmony an orientalist critique and the constitutionalist critique of Iranian government and society. In this view, for an Iranian to read Hajji Baba would be an education in the orientalist perspective, placing a pre-eminent orientalist critique as the source for constitutionalist politics. On the other hand, Mīrzā Habỉb's involvement would tend to have to complicate the picture in the manner I have just discussed, complicating the possible readings of the text available to an Iranian readership.

The debates outlined above concerning the part orientalists had to play in the ascribing of a social value upon the Persian translation of Hajji Baba touch upon the questions of textual invocation of a readership, and the possibilities for wilful misreadings of a text. For, in the view of orientalists such as Phillott and Browne, the understanding of the currency of the translation of Hajji Baba into Persian could be rationalized through either of at least two moves. First, the text's use of an orientalist critique fit into the aspects of the constitutionalist movement that engaged in social 
critique, as opposed to materially anti-colonial discourse-Browne, for one, in his discomfort with the latter aspects of constitutionalism, would exemplify such a perspective. So, as he and others valourized Morier's work as an accurate critique of then-contemporary Iran, they anticipated that the Iranian reading of the book would be a sort of education of an Iranian public in the orientalist critique offered by the text. The other possible explanation may be that, for other critics, the text's orientalist critique is simply 'history and not burlesque'. Nonetheless from this perspective, the Iranians, while admirable to orientalists in their efforts to utilize the text for social reform, were doomed to some extent to mis-apply it, as even their reformist leaders were implicated in 'obnoxious' sects that used irrationalism as their ideological basis. This reading reifies a potential for the mis-reading of the text, while valuing it negatively.

\section{The Character of Hajji Baba}

The complex history of the various misidentifications of and debates around the author(s) of Haji Baba should not obfuscate a careful reading of what is in any case largely a remarkable work. Here I will advance a reading of the character of Hajji Baba that will examine the manner in which the imagining of a character invested with incredible powers of social mobility and transience is significant to a text that has circulated in both British orientalist and Iranian reformist imaginations.

Hajii is, first of all, born of low means ('the son of a barber'); a factor of clear significance in his circuitous journeys that span from Central Iran to the border of Persia and Russia (present-day Armenia) to Turkmenistan to Baghdad and even Istanbul. The book ends as his journeys are about to continue on to England. The characterization of him as 'a rogue', which is the term most used by British reviewers to describe him, is based on the fact that Hajii's moral qualities remain largely, as far as the plot is concerned, unformed. At any given moment, his response to a specific situation may be based on criteria that are more central to developing certain qualities of the plot than to developing a 'round' character of Hajji. ${ }^{35}$ That he will act on the basis of respectable intentions on one page and of an amoral selfishness on the next is a quality that largely allows for the imagination of his social mobility. Deidre Shauna Lynch has argued that this model of character conforms to a trend in 18th-century literary character production that:

is supposed to be a means for producing a sense of social context (rather than the social context counting as a means for producing our sense of a character): this character is the prosthetic device that enables readers to apprehend the comprehensive, impersonal systems that bind them together. ${ }^{36}$

That Hajji is more or less simply a 'prosthetic device' for an investigation of Persian culture and society is borne out by the manner in which critics and reviewers have been able to legitimize their generalization of his story to an understanding of this 'culture' at large. This ethnographic reading of Hajji Baba is very greatly bolstered by his 'flat' and unformed character (both in a moral and a physical sense).

Hajii is himself unidentifiable, bereft of characteristics, while the characters he meets are charged with an adjectival fecundity. For example, Osman Aga, Hajii's first mentor, is described as 'a short squat man, with a large head, prominent spongy nose, and a thick, black beard'. ${ }^{37}$ Noses, ears, beards and body shape are a part of what distinguishes 
each character from the other, thus outlining a continuity of differences in a coherent social environment. Conversely, Hajii is identified only through detailed descriptions of the changes of costume his many social transformations require: from a merchant's assistant to a Turkmen slave-fighter, from a mendicant qaliyan-vendor to a wealthy merchant, from an assistant to the court physician to being one of the royal executioners, Morier details at length the costume Hajii's new position assumes, and often goes so far as to describe the price and manner of its purchase. Chapter XVII, which is subtitled ' $\mathrm{He}$ puts on new clothes, goes to the Bath, and appears in a New Character', is entirely dedicated to one such transformation. The detailed description of not only the clothes required for Hajij's new station in society, but also the act of shedding his old ones and enrobing in the new attire, locates the development of Hajji's character on the empiricization of this act. At the end of the above-mentioned chapter, the act of enrobing is explicated in tedious detail-I will quote it at length in order to draw attention to the mode of its description:

As soon as it [the bath] was all over, the dalak brought me some dry linen, and conducted me to the spot where I had left my clothes. With what pleasure I opened my bundle and inspected my finery! It appeared that I was renovated in proportion as I put on each article of dress. I had never yet been clothed in silk. I tied on my trousers with the air of a man of fashion, and when I heard the rustling of my vest, I turned around in exultation to see who might be looking at me. My shawl was wound about me in the newest style, rather falling in front, and spread out large behind, and when the dagger glittered in my girdle, I conceived that nothing could exceed the finish of my whole adjustment. I indented the top of my cap in the true Kajari, or royal style, and placed it on my head considerably to one side... ${ }^{38}$

Hajji's pleasure at the sight of his new clothes is commensurate to the 'renovation' to which the clothing leads. When he 'turns around in exultation' to catch the eye of an admirer, it is to appreciate the 'finish of the whole adjustment' made to his character. That in the chapter sub-title the author (who, solely in this aspect of the text, is not Hajii) proclaims the end to this process to be the creation of a 'New Character' is an overadmission of the utility of such a character for the aims of the narrative: while Hajij exits the bath invested with the history of the narrative, he is easily rewritten as new in his entrance into a different social sphere. Thus the various social spheres are imagined as interrelated in an imaginary whole that is subsumed under the conception of a society's 'Manners and Mores'.

While distinguishable in his costume, Hajji is clearly in other ways unmemorable to his companions - for in nearly every reunion with a previous friend, he must remind his friend of his identity. However, most often the tendency towards his mis-recognition is a cause for Hajji's success: in one episode Hajji is unfairly implicated in the death of the royal court's head theologian and thus deems it necessary to flee Iran (chs LVII-LXII). In the course of his escape, Hajij meets up with a caravan and only later realizes that one of the enshrouded bodies the caravan is taking for burial near a Shi'a shrine is none other than that of the deceased mullah, and that the latter's entourage is travelling in the caravan as well. However, despite his terror at being discovered, at first Hajji finds that no one recognizes him, even as they curse his name before him. The simple act of changing costume has transformed him so much that even the Mullah's servants, who 
once knew Hajji personally, cannot recognize him. In this, his tendency to not be recognized is one of the causes for his surviving adventures that lead to the death of others around him who are physically distinguished (i.e. Mulla Nadan, his companion in the above-mentioned episode, who miscalculates and is executed after choosing the incorrect clothes to present himself in). Later, when he is finally discovered, it is for having swindled one of the travellers out of some money. However, he is quickly saved by the coincidental attack of a Kurdish tribe on the caravan, which allows him to escape unnoticed. His recognition, linked not to characteristics but to 'character' (as in a moral character), differentiates between the (in)visibility of Hajji's characteristics and his internalized roguish tendencies. So, despite his ability to adopt multiple visual significations within the social fabric, his character remains unchangeable.

A tendency toward Hajji's mis-recognition allows for the mapping of an Iranian social space as a unified, comprehensive and knowable system. As I will discuss later in more depth, this mapping follows developments in the orientalist imagination of the Orient. These developments move from an emphasis on the fantastic and incommensurable aspects of the Orient to a rationalization of it on the terms an increasingly penetrating mode of colonialism. Mapping the social space created a sense of the potential for its dominance and, more importantly, a moral justification for desires to do so. What is more difficult to settle is the issue of whether the character of Hajji Baba was to be a suitable vehicle for the deployment of an imagination sympathetic to the Iranian constitutionalist discourse, albeit through translation. While, as I have argued, certain evidence leads to the conclusion that the translation of Hajji Baba occurred as a result of myriad reasons with rationales that could be coded both 'social/political' or, conversely, 'literary', there is no doubt that its circulation and endurance was brought on by an ever-increasing interest on the part of a politically awakened audience in Iran for new forms of writing. Entwined in this is the simultaneous conceptualization of a 'national literature' for a modern nation, Iran, which would rely on one language, Persian, for the linguistic unification of the nation. In this context, there are several ways to interpret the attraction of the character of Hajji Baba to an Iranian audience. To begin with, the mode of character employed for Hajji Baba is not necessarily one 'foreign' to Iran; the socially mobile and 'flat' character has certain corollaries in traditional literary modes such as epic poetry and oral tales, as well as in certain written work. In any case, a simple (and not illegitimate) approach would argue for the reading of the character of Hajji Baba as somehow related to 'traditional' characterization in Persian literature.

However, there may be more convoluted issues at stake in the character of Hajji Baba as he was read by an Iranian readership. This topic is perhaps one location where possible affinities of Iranian constitutionalism to 19th-century orientalism may be theorized. These affinities will probably be loose and ambivalent, more a by-product of these discourses than a feature of them. A mis-reading of Hajji Baba's bereft-ofcharacteristics character may offer us various allegorical spaces for imagining the interpellation of an Iranian reformist reader into the 'dear reader' conversation (annunciated in the final paragraph of the book in the words 'gentle reader!'). The characteristic-less protagonist is, notably, a quality of Marāghihì's Siyāhatnāmih-i Ibrāhìm Bayk. Ibrāhīm Bayk is as thinly constituted a character as is Hajii Baba, even though his 'flatness' is more a result of an exceeding naïveté, where Hajji's is due to his moral vacuity. What is similar about both characters is their ability to traverse social boundaries, so as to 'apprehend the comprehensive, impersonal systems' that constitute the Iranian nation, itself a conception of a recent history. 
Firoozeh Kashani-Sabet, writing on the development of conceptions of national boundaries and national space in Iran in her book Frontier Fictions, argues that the constitutional revolution played an important part in the process of defining an Iranian nation. ${ }^{39}$ The constitutionalists were very drawn to the discourses of nationalism that were spilling over from post-Enlightenment Europe, and which were being adopted by Iran's neighbours, particularly Ottoman Turkey. The agenda of reform they envisaged was largely in the context of such a nationalist discourse, even as it took on a nativist sheen. That the characters Hajji Baba and Ibrāhīm Bayk were empowered, through their lack of characteristics, not only to detail the contiguity of social classes, but also to contain these within an imagination of a unitary national space, was something of great importance to constitutionalists; in previous Iranian literature, nowhere were there examples that could so effectively map a seamless national space where a narrative would run its course. This is most clear in the text when Hajji Baba travels to Turkey; the events that befall him there (particularly the ill fated marriage he proposes with a Turkish woman; chs LXVI - LXXI) largely work to reinforce not only his identity in terms of its difference from that of a Turkish or Arab identity, but to also develop a similar difference in terms of the imagination of a social space, and link his identity to the social space and geography of Iran.

While in the British context it is possible to see the character of Hajji Baba as not only continuing a mode (or trope) identified by Lynch as one that maps the circulation of cultural value through a social space, it furthermore developed a fictional narrative on the basis of penetrating and mapping Persian society in keeping with developing trends in British colonial discourse. While the old Oriental Tale emphasized an exotic otherness about the Orient, Morier was able to innovate the genre in such a way so as to reflect the shifts that were occurring in colonial discourse between a discourse of othering and one of knowing. ${ }^{40}$ The histories of colonialism are largely inflected by the conflicts between these often contradictory impulses, and the ascendancy of one tendency was often prefigured within shifts in political and economic relations between colonial centres and outposts.

Hajji Baba's social mobility and lack of identity allow the reader to imagine the Persian social space as knowable, quantifiable, and definable. This desire had certain affinities with the discourse of Iranian constitutionalism: the desire to quantify and map the nation were parts of the imagination of reformist Iranians who wished to pursue nationalist models that were part of earlier reform movements in France, Britain as well as in parts of West Asia. Not only did Hajji Baba necessitate a skilful translator such as Mīrzā Habìib to render it readable, but also the readers of Hajji Baba were historically positioned so as to be able to interpellate the text, so as to translate for themselves the imaginary spaces of the book as relating to the material struggles they were engaged in. Thus the character of Hajji Baba - which in the Iranian context was a cousin of other characters in the contemporary fiction of the time such as Ibrāhīm Bayk-was able to operate simultaneously within the seemingly contradictory discourses of mid-19th-century orientalism and fin de siècle reformist constitutionalism in Iran.

\section{Receptions and Readerships of Hajji Baba}

The English version of Hajji Baba was to become 'enduringly popular', and Patrick Brantlinger argues persuasively that part of this popularity relates to the book's reproduction of ideals of social advancement that relate directly to Britain. This is quite 
plausible, given Hajji Baba's eventual association with British diplomats, and his choice as part of the Persian diplomatic delegation to England. ${ }^{41}$ However, the popularity of Hajji Baba was not at first a foregone conclusion, and, despite the redemptive plot, the initial review of Hajji Baba of Ispahan in Blackwood's Edinburgh Magazine offers a view of British reception of the text that would argue that the book fell very closely on the cusp of a change in the relationship of the reading public to the 'Orient'. This is born out to some extent by comparing the basis of value established by this review to the manner in which later reviewers valued the text. Blackwood's Edinburgh Magazine's review of the book as, on one hand, ethnographical, and on the other hand fantastic, remained the measure for most reviewers. The anxiety contained in the Blackwood's Edinburgh Magazine review reflects concerns touched upon in the previous discussion on the character of Hajji Baba; indeed, the character is the locus for the reviewer's dissatisfaction with the book. As Britain's colonialist discourses developed in line with changes in the material aspects of colonialism, so did literature begin to re-imagine the Orient to reflect these changes.

Blackwood's Edinburgh Magazine devoted seven pages to its rather detailed review of Hajji Baba that appeared in the January 1824 issue of the influential publication. The review, while largely unfavourable to the book, outlines in a comparison with Anastasius the qualities of an Oriental Tale that are considered valuable to the anonymous reviewer, who invokes public taste as his or her measure. ${ }^{42}$ Where Anastasius is 'a work of immense genius, and natural power', displaying 'an extraordinary acquired talent for drawing $\mathrm{MAN}$, as he is in one particular country; but still more extraordinary intuitive talent for drawing man, as he is in every class, and in every country', Hajji Baba is an abject failure. ${ }^{43}$ This glorification of the talent that is associated with the outlining of national characteristics is one part of the intuition that will generate a universalizing representation of 'man' outside the bounds of social and cultural 'characteristics'. It is of course the presumption of the reviewer that the goal of all literature, including the Oriental Tale, is the achievement of such a universal perspective on man-presumably primarily the European man. Thus, while Anastasius is an Eastern character riddled with 'vices' and thoroughly distinguishable from the reader's own experiences, he nonetheless 'never thoroughly loses the sympathy of the reader' because: ${ }^{44}$

There is a rag of good feeling - a wretched rag it is, and it commonly shews itself in the most useless shape too (in the shape of repentance)-but there is a remnant of feeling about the rogue [Anastasius], (though no jot of moral principle,) and a pride of heart, which, with romance readers, covers a multitude of sins; and upon this trifle of honesty, (the very limited amount of which is a curiosity,) joined to a vast fund of attractive and unpopular qualities - wit, animal spirits, gay figure, and personal courage- he contrives, through three volumes, to keep just within the public estimation. ${ }^{45}$

This 'public estimation', however, is not to be well engaged by the qualities of Hajji Baba, which the reviewer finds 'materially' at odds with the public's ideal. 'Starting as a barber, is starting rather low; and it is one material fault in our friend Hajji Baba, that, from the beginning to end, he is a low character'. ${ }^{46}$ While the prejudice of class-origin is a barrier to the reviewer's empathy for Hajji Baba, this prejudice is one that is aggravated by his inability to shun the characteristics of his class: 'Obscure birth is no bar to a man's fortune in the East; nor shall it be any hindrance to him among us; but we can't take 
cordially, East or West, to a common-place fellow'. ${ }^{47}$ Furthermore, the issue is not merely class characteristics, but also the projection of these qualities onto the character's very immaterial self. This marks the crucial difference between the empathetic Anastasius and the un-likable Hajii Baba. 'Anastasius is meanly born, but he has the soul that makes all ranks equal.' Thus, even Anastasius' roguish qualities are mitigated by the fact that he is a 'rascal like a gentleman', an 'advantage' denied Hajji Baba. The difference between them, however, is the irreconcilability of Hajji's 'common-place' characteristics - characteristics that were to eventually be valued as ethnographic. That the 'common-place' Persian was no fair topic for a novel reflects the desires of a public for a tale with 'exceptional' characters, not for representations of what was felt to be no more than the oriental norm. This quality of Hajji Baba was to be that which endowed the character and book with a lasting value through the course of late colonialism and even afterwards.

In the language cited above, another question arises: the relationship of the reviewer to the 'public', which is an undefined body of a seemingly singular mentality. The public is cited at other important points in the review (e.g. '[the book] falls so very far below what the public expected ${ }^{48}$ ) but it is also implicated in the reviewer's reading of text itself, when the reviewer claims that 'profiting by the example of the Persian story-tellers, he pauses in his tale at the most interesting point, and says to the public, "Give me encouragement, and I will give you more'. ${ }^{49}$ This is an expansion on the ideal of the 'dear reader' statement, and here the reviewer clearly reads the statement as one intended to address the public-at-large. This collapse of the notion of an individual reader with specific characteristics (i.e. the Literate Gentleman, or the Young Scholar, etc.) into a readership that involves the entire 'public' points to the manner in which the Oriental Tale's readership was not to be envisaged within the singular terms of the 'reader', but rather was considered part of an imagination that is part of the rights and expectations of the public. ${ }^{50}$ This notion of the public must therefore relate to a sense of the unity of the British social environment, and reflect the manner in which a book like Hajji Baba cannot but be implicated in the national aims as they were articulated in colonial discourse.

Given this concern with the public/nation, it is not surprising that the reviewer's strongest criticism of Hajji Baba is reserved for a discussion of the ending of book, where Hajji Baba begins his association with the British consular officials and the Shah's Vizier, and eventually is assigned to a delegation that is to travel to Britain. Here, the comic digressions between Hajij, the Vizier and others, which are meant to display the pathetic ignorance of the Persians of anything European, arouse great displeasure in the reviewer, for whom it 'is, to speak the truth plainly, very wretched stuff indeed'. ${ }^{51}$ The anxiety here is with any representation of England through the eyes of an oriental, even if they are meant to signal the oriental's ignorance. This anxiety leads to the final assessment of the text, which argues that 'seriously, Hajji Baba should be cashiered forthwith. As far the public is concerned, the journey of the "pilgrim" should be at an end. And indeed, England to be described by any foreigner is a subject just now not the most promising' ${ }^{52}$ The reviewer's anxiety concerning the depiction of England by a foreigner is thus complicated by the alleged desire, once again, of the public, for whom and to whom the reviewer claims to be speaking. Here the conception of the public's desires is clearly linked to the integrity of the nation (and the empire), for, in reading Hajji's take on 'the Franks', the reviewer exhibits anxieties over a possible critique of English society emerging from 'any foreigner' - which by its saying confuses Morier with his character, 
Hajji, who is the foreigner mentioned. The undeniable irony of such an anxiety (i.e. the currency of a description of Persia by Morier not matching the 'promise' of the latter's character describing England) is not to be registered by the reviewer and is subsumed with in the concerns of what are claimed to be the public's desires.

What this concern with the 'public' betrays is a concern with the growing power of novels to impact collective imaginations - this despite the relatively modest circulation of the first print run of Hajji Baba at 1250 units. ${ }^{53}$ Even though the first edition was to sell out within a few months, the reviewer's estimation of the novel, and the constant references to 'the public', would intimate an emerging confluence of the power of novelistic writing over public imagination and national identity that seems far out of proportion to the small initial circulation of the novel. Later reviewers attempted to reevaluate the novel and assess its cultural value on the basis of criteria not used in the Blackwood's Edinburgh Magazine review. Some complain of the fact that the novel is rather long, or that many passages appear irrelevant to the narrative and seem to function only to describe specific cultural or social scenarios that Morier appears to find of personal interest-however, the re-reading of Hajji Baba as literary ethnography imparts an entirely new kind of value upon the novel. And so, by 1895, E. G. Browne could without pause claim that 'Every cultivated Englishman who has not read Hajji Baba (if, indeed the Englishman who has not read it can, in the full meaning of the term, be described as cultivated) should at once proceed to remedy this defect in his education'. ${ }^{54}$ That Browne equates the reading of Hajii Baba to 'education' is quite telling within the conception of role of this kind of Oriental Tale. Browne can further distinguish where the Blackwood's Edinburgh Magazine's reviewer cannot, when he states that 'Considered merely as a piece of fiction, Hajji Baba has many rivals; considered as a faithful picture of the living East (as opposed to the purely imaginary and unreal East of Moore and Southey), it has none'. ${ }^{55}$ The valuing of Hajji Baba, which may not have shone in the ranks of the Oriental literature of its day, was clearly to be rethought by the time of Browne's writing, and Browne very transparently delimits the new assessment of the text's value as a 'faithful picture of living East' in opposition to the flights of fantasy constructed by the likes of Moore and Southey. The distance between Browne and the Blackwood's Edinburgh Magazine reviewer is formidable, but is one that may be plotted along the lines of the development of British colonial discourses over the 19th century. So while both may claim some reflectivity of the desires of the public, it is possible to read these claims as arising from the trajectory of colonialism, as mentioned, from othering, to knowing. What drives the Blackwood's reviewer's anxieties is the transition from the mode of Oriental Tale (e.g. Anastasius) that others the Orient, to that of Hajji $B a b a$, which aims to know it. The valourization of Hajji Baba by later reviewers, particularly orientalists such as Curzon and Browne, is largely a reflection of the ascendance of the colonial discourse of knowing in a public sphere.

The issue of the readership of Hajji Baba in Persian is a matter that may require more conjecture than one would prefer, but there are specific points of interest that would tend to create a framework for understanding its readership. Iranian society in the early part of the 20 th century was of a great majority illiterate. While by the early part of the century a number of small exclusive schools offered secondary education, the great preponderance of students received their primary education in the religious madrasa system. The madrasa system emphasized learning through rote exercises for the purpose of a basic religious education rather than for anything that might approach an education for literary appreciation: those who chose to stick with the religious system of education became 
seminarians following an education rooted in religious studies. Furthermore, this system was largely closed to women, who could gain education only in informal settings, or from family members-although this policy was already challenged both by sectarian or minority religious groups such as Babis and Armenians as well as by the nascent secular education system in Tehran. The system of the religious educational institutions nonetheless bred the majority of the reformist constitutional revolutionaries, who were by and large highly educated in Persian, Arabic and Turkish literary histories, particularly poetry. Not a few of these figures were also educated to some degree in French and English, while some knew German. The knowledge of Persian literature obtained by this class of men largely was a result of private and informal efforts or of studies undertaken in Baghdad, Istanbul, Baku, or other cities in areas neighbouring Iran. However, beyond the oral transmission of poetry, the great majority of people were not literate, and those who were did not have access to an education that would have accommodated an interest in Persian literature. Given these conditions, it is puzzling to understand why Shaykh Ahmad would have asked E. G. Browne for assistance in having $H \bar{a} \bar{a} j \bar{\imath} B \bar{a} b \bar{a}$ published. As others in his milieu were, Shaykh Ahmad was deeply committed to introducing social as well as political reforms to Iran; and yet mass literacy was a very distant goal. How then would the publication of $H \bar{a} \overline{a j} \bar{i} B \bar{a} b \bar{a}$ fit into these concerns?

We do know that the newspapers in which Shaykh Aḥmad and Mīrzā Habìb were involved in the production, Akhtar central among them, reached audiences through public readings and the circulation of used newspapers and pamphlets. ${ }^{56}$ Memoirs from these times do contain references to the public reading of both newspapers as well as books, and these were largely carried out in the setting of clandestine meetings of banned political organizations, where issues of the day were to be discussed. These secret gatherings constituted the local and grassroots educational institution engaged in the replication and reproduction of the political themes of reformists and constitutionalists. $\mathrm{N} \bar{a}$ 'im al-Islām, a historian contemporary to the constitutionalist period, recalls meetings where selections from Ibrāhim Bayk were read out loud, drawing the participants to tears, and notes also that some of the participants had most of the book memorized. ${ }^{57}$ These meetings provided the settings for the reading of texts such as $H \bar{a} \bar{a} j \bar{i} B \bar{a} b \bar{a}$ within the context of a political reformist discourse. While we do not have specific citations of $H \bar{a} \bar{j} j \bar{\imath} B \bar{a} b \bar{a}$ as being a book of choice for such circles, what can we make of Shaykh Ahmad's claim to Browne that 'I know of the fact that in Iran a great market and interest exists for' it? The market and interest alluded to by Shaykh Ahmad is probably a market of such reading-circles, where the interest of politicized Iranians for new literary forms to reflect their desire for political and social reforms came together with a translation of uncommonly innovative use of Persian colloquial to generate deliberate mis-readings of Morier's book. Thus can we begin to reconcile the divisions between political and literary value that came to enshrine Mìrzā Habib's work as one of the most notable achievements in Persian of his era, and also locate a readership for the book, within the clandestine reading-circles of the constitutionalists, which would resolve the question of the reader called to in the final paragraph of the book: 'And here, gentle Reader! the humble translator of the Adventures of Hajii Baba presumes to address you, and, profiting by the hint afforded him by the Persian storytellers, stops his narrative, takes a bow, and says "Give me encouragement and I will tell you more." "58 Mīrzā Habīb had only to smile as he finished his translation, for his own postscript was already written. He had only to re-read it. 


\section{A Circle of Readers: Appropriate Readings, Authorial Recognition}

Further questions remain for the moment outside the purview of this study, but are no less pertinent to our thesis. To fully account for the transactionary nature of Hajji Baba in its movement between English and Persian readerships, a missing link-the French translation used by Mīrzā Habib - is as yet a matter largely unexamined. ${ }^{59}$ A textual analysis of the three editions-English, French and Persian-will afford a deeper understanding of the mechanics of the transactions between these different versions. While some scholars have already made insightful comments by comparing Morier's text with that of Mirzā Habỉb, the elision of the French intermediary text has been an unfortunate oversight in these studies. ${ }^{60}$ Only Gianoroberto Scarcia's somewhat general comments on the innovations of Mìrzā Habỉb's prose consider the French Defauconpret translation at all. ${ }^{61}$

While the readerships of Hajji Baba were clearly differently constituted in the British and Iranian contexts, there are affinities between the prevalent discourses of each readership that allowed for its migration through the act of translation. Complicated by misrecognition, the writing of Hajji Baba was initially as overdetermined as its readership was unrecognizable. When the Blackwood's Edinburgh Magazine reviewer of the book assumed the reflection of the position of public desires, he or she was misrecognizing the development of the fantasies of the public through the desire for knowledge of the Orient. In the Iranian context, Mīrzā Habỉb's able translation was given cultural value through Shaykh Ahmad's attempts to have it published. That he was only successful in this through death confirms the potentials for its value within the constitutionalist imagination, even as it led to a misrecognition of the translator.

These misrecognitions clearly affected the critical conceptions of the two texts, and affected later readings of them. Twentieth-century critics of the English edition moved away from the assessment of the value of the text as relating to its ethnographic scope, and thus attempted to deflate the book of its initial value, which in the 19th century clearly related it to the colonial discourse of that historical moment in British colonialism. Edward Said notes that Hajji Baba is an example of cultural discourse utilizing 'the Oriental motif' as 'not principally a stylistic matter' ${ }^{62}$ Indeed, the recovery of Morier's text by Walter Scott, and later by fin de siècle orientalist scholars, is based on an assessment of the text's value precisely for the reason that it does not simply treat the Orient as simply an issue of style. The ethnographic turn in the Oriental Tale genre was in fact foretold by the approach of Morier in Hajji Baba. Critics of the Persian text, however, led on by the misrecognition of the translator by Browne and others, read the book within an erroneous political context, greatly reducing the complexity of the production of that text. When looked at through the context of deliberate counterinterpellation, the Iranian readership of Hajji Baba could not have been drawn into the critique of their society presented by Morier. The critique they were drawing from the book, enervated by the character of Hajji Baba, was a critique that reflected the ambivalences of Iranian constitutionalism, which was at once nationalist, and thus engaged in Enlightenment thought, and yet fiercely anti-colonialist, and thus nativist in its self-conception. Brought back to the final paragraph of the book, and the first paragraph of this paper (and now the final paragraph of this paper), a question resurfaces: can the polite 'gentle reader' addressed by the 'author' of Hajji Baba have been so directly interpellated into the ideological imperatives of the text? The context of a historical and textual investigation of the narrative would lead, rather, to our having to 
imagine readers in part filling the book, just as they were expected to fill the character of Hajji Baba, with their own imaginations and desires, and thus deflating the power of the call of the text and reconstituting it for their own reading needs.

\section{Notes}

1. I must acknowledge my debts to a number of individuals who have offered very useful comments on different versions of this paper, in particular Gauri Viswanathan, Hamid Dabashi, Michael Beard as well as an anonymous reviewer for Middle Eastern Literatures.

2. The literary innovations of late-19th-century Iran and their relationship to the constitutional revolution are widely discussed in Persian-language scholarship, especially in Bāqir Mu'minī, İ $r a ̄ n$ dar āstānih-yi mashrūtị̂yat va adabīyāt-i mashrüțih, Tihrān: Nashr-i Sipīdeh 2537, 1978; and Muhammad 'Al̄̄ Sipānlou, Nevisandigān-i pishhrau-i İ̃ān, Tihrān: Mu'assessih-yi Intishārātīi Nigāh and Humā Nāṭiq, Az māst ke bar māst, Tihrān: Intishārāt-i Āqā, 1978. Several English-language sources also attend to this question, including: Mohamad Tavakoli-Targhi, in Refashioning Iran: Orientalism, Occidentalism and Historiography, New York: Palgrave, 2001. See also Kamran Talattof, The Politics of Writing in Iran: A History of Modern Persian Literature, Syracuse, NY: Syracuse University Press, 2000; and Hassan Kamshad, Modern Persian Prose Literature, Bethesda, MD: Ibex Press, 1996.

3. What Pierre Bourdieu terms the field of cultural production presents a useful framework from which to trace these cultural transformations and innovations. Bourdieu uses the field of cultural production to describe the system of social values and beliefs that, working in a complex network of relations, make legible and accede material and immaterial value to the work of the artist/cultural producer. Yet Bourdieu's work presents certain limitations that must be contended with-specifically, a degree of Eurocentrism where the fundamental values of the field of cultural production are identified, as well as a lack of consideration for inter-linguistic and inter-societal literary relations. These concerns are clearly not significant enough to discount the use of the theory of the field of cultural production outside the confines that Bourdieu himself used it for. As a productive framework, it may be extended to accommodate different cultural settings, and multiple cultural settings, through a following of its own fundamental claims. Put simply, the logic of the cultural field is an economic logic. Yet, any consideration of the circulation of texts across these discrete literary fields will require a complication of Bourdieu's theory, which does not consider the relations between the fields of different societies. As cultural capital accrues from the logic of a specific field, and from the struggle between forces within each field, it will be necessary to conceive of how such cultural capital is affected in its transfer between different social settings. This study will work with this problem by suggesting the term transaction as way to narrate and analyse the movement of texts across different fields of cultural production. For more on Bourdieu's theorization on the economy of the field of cultural production, see Pierre Bourdieu, The Field of Cultural Production, European Perspectives, ed. Lawrence Kritzman, New York: Columbia University Press, 1993.

4. Garrett Stewart, Dear Reader: The Conscripted Reader in Nineteenth-Century British Fiction, Baltimore, MD: Johns Hopkins University Press, 1996, pp. 27, 397.

5. The study of the social value of texts for certain readerships, as pursued in this essay, follows from a body of scholarship in English literary historical studies examining the changing social value of reading and consumption of literature in the 19th and 20th centuries. Among these are: Richard Altick, The English Common Reader, Chicago, IL: University of Chicago Press, 1957; Patrick Brantlinger, The Reading Lesson: The Threat of Mass Literacy in Nineteenth-Century British Fiction, Bloomington, IN: University of Indiana Press, 1998; as well as Franklin E. Court, Institutionalizing English Literature: The Culture and Politics of Literary Study, 1750-1900, Stanford: Stanford University Press, 1992.

6. Ian Jack, British Literature 1815-1832, Oxford: Oxford University Press, 1963, p. 245.

7. This popularity is as 'enduring' on the Iranian side as among Anglophone readerships, if not more so. This is evinced by the continual re-printings of earlier editions, and the continuing interest in the text by Iranian literary critics and scholars. The popular novelist and literary critic Ja'far Mudarris Șādeghî edited an edition in 2000 based on the original manuscript of Mìrzà Habib's handwriting, which

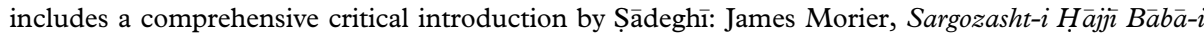
Isfahānī, ed. Ja'far Mudarris Șādeghī, Tehran: Nashr-i Markaz, 2000. 
8. Shaul Bakhash, Iran: Monarchy, Bureaucracy and Reform under the Qajars: 1858-1896, London: Ithaca Press, 1978, p. 305.

9. Humā Nātiqu, $A z$ Māst Ke Bar Māst, Tehran: Intishārāt-i Āqā, 1978, p. 102.

10. 'Hajij Baba of Ispahan', Blackwood's Edinburgh Magazine, LXXXIV (1824) 51.

11. Walter Scott \& Ioan M. Williams, Sir Walter Scott on Novelists and Fiction, London: Routledge \& K. Paul, 1968, p. 357.

12. The introductions to two editions of Hajji Baba by Richard Jennings (1949) and Richard Altick (1954) both display a similar ambivalence concerning the literary value of the text.

13. Edward Granville Browne, A Literary History of Persia, 4 vols, Cambridge: Cambridge University Press, 1959, p. 468: 'In this connection mention should also be made of the Persian translation made by the talented and unfortunate Hajji Shaykh Ahmad 'Ruhi' of Kerman of Morier's Hajji Baba ...'

14. These debates are described in detail by Humā Nāțiq, 'Ḥājjì Morier va Qișsih-yi Isti'mār', Alefbā (no date), 22- this article was generously made available to me by Dr Mehdi Khorrami, yet does not contain the date or issue of the publication. Also, it is a curious coincidence, perhaps, that, in appropriating the Ali Baba narrative from an unrelated source for inclusion in his 1701 'translation' of Mille et un nuits, Galland indicates in his extant notes that the original name for the famous character was 'Hogia Baba'. Aboubakr Chraïbi, 'Galland's "Ali Baba"' and Other Arabic Versions', Marvels \& Tales, 18/2 (2004) 160.

15. Yahyā Āryānpūr, $A z$ Sabā Tà Nìmā, vol. 2, Tehran: Entesharat-i Zaddar, 1994, p. 395. Useful biographical information on Mìrzā Habīb may be also be found in the aforementioned edition of Ḥàjjì Bābā prepared by Ja'far Mudarres Șāedeghī.

16. 'Mīrzā Hạỉb Iṣfahānì', Akhtar, 23 May 1893, p. 206.

17. Ibid.

18. Āryānpūr, $A z$ Sabā Tà Nìmā, vol. 2, p. 395.

19. Muhammad Khān himself died under suspicious circumstances after he was exiled from Tehran to Mashhad by Nāṣir al-Dīn Shāh in 1866. See: Amanat, a, Pivot of the Universe: Nasir al-Din Shah Qatar and the Iranian Monarchy, 1831-1896, London: IB Tauris, 1997, p. 398.

20. Āryānpūr, $A z$ Sabā Tà Nìmā, vol 2, p. 395.

21. One such poem is in a collection Khān Malak Sāsānī, Yādbudhā-yi Sifärat-i Istānbūl, Tehran, n.p., 1966, p. 162.

22. Mīrzā Ḥabīb Iṣfahānī, Khațt Va Khațtātạān, Tehran: Kitābkhānih Mustawfî, 1991.

23. I am told by Manuchehr Kasheff, instructor of Persian at Columbia University, that Mîrzā Habỉb is known to have produced a remarkable body of obscene/pornographic poetry as well, which circulated in Iran as well as among émigrés abroad. Also, the portrait drawn of Mìrzā Habỉb by the Iranian travelogue writer Ḥājjī Pîrzādeh confirms his less than refined habits and manners, which are subject to Pīrzādeh's condemnation despite his admiration of Mīrzā Habīb's literary skills. See: Pīrzādeh, Muhammad 'Alīi, Safarnāmeh-yi Hậjjì Pìrzādeh, Tehran: Intishārāt-i Bābak, 1360/1981, vol. 2, pp. $94-96$.

24. This is mentioned in Jamalzadeh's introduction to his edition of the text. See: James Justinian Morier, in M. A. Jamalzadeh (ed.), Sarguzasht-i Heâjjì Bābāa-yi Isfahānī, Costa Mesa, CA: Mazda Publishers, 1996. Also, a 1952 edition of Hajji Baba in Persian, apparently the first edition to be published in Iran, states that it is 'based on two written manuscripts and two Calcutta editions'-more evidence of a second edition that may have been contemporary to Phillott's. See: James Justinian Morier, Sarguzasht-i Hiājō Bāba $-y i$ Isfahānī, Tehran, n.p., 1330 [1951/52]. Of note is also the fact that if the 1952 edition is the first domestic Iranian printing of Hajji Baba, its timing is rather provocative, coinciding as it does with the nationalization of oil by Mossadeq and the exiling of Muhammad Reza Shah until his restating in a CIA-organized coup.

25. Morier, Sargozasht-i Hiājōi Bābā-i Isfahān̄i, p. 10.

26. James Justinian Morier and D. C. Phillott, Sarguzasht-i Hiājì Bābā-yi Isfahān̄ì (a Persian Translation of Hajii-Baba of Ispahan), Calcutta: Baptist Mission Press/Asiatic Text Society, 1905, p. vii.

27. Ibid.: ix.

28. Ibid.: ix $-\mathrm{x}$.

29. Ibid.: vii.

30. Amanat, Pivot of the Universe, p. 443.

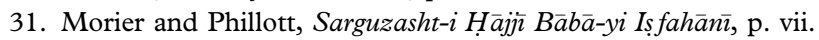

32. There is no indication that Mìrza Habỉb knew English, although he translated Gil Blas and plays by Molière from French into Persian. So, it is quite likely that Mìrzā Habỉb worked from a French 
translation, of which one was published within a year of original the publication of the English. For more on Mīzā Habìb's translations from French literature, see: Maryam B. Sanjabi, 'MardumGuriz: An Early Persian Translation of Moliere's Le Misanthrope', International fournal of Middle East Studies, 30/2 (May 1998) 251-270.

33. Morier, Ișfahān̄̄ and Jamālzādih, Sarguzasht-i Hajî Bâbâ-yi Isfahân̂, Mirza Habib Isfahani (trans.) and M. A. Jamalzadeh (ed.), Costa Mesa, CA: Mazda Publishers, 1996, p. 15.

34. Edward Granville Browne and Abbas Amanat, The Persian Revolution of 1905-1909, Persia Observed 2, new edn, Washington, DC: Mage Publishers, 1995, p. 93.

35. The term 'round characters' is used here in the same way that as that defined in Deidre Shauna Lynch, The Economy of Character, Chicago, IL: Chicago University Press, 1998.

36. Ibid.: 87 .

37. James Justinian Morier, The Adventures of Haiji Baba of Ispahan, London: Cresset Press, 1949, p. 18. All further references to the English text of Hajji Baba will be to this edition, unless otherwise noted.

38. Ibid.: $93-94$.

39. Firoozeh Kashani-Sabet, Frontier Fictions: Shaping the Iranian Nation, 1804-1946, Princeton, NJ: Princeton University Press, 1999, p. 85.

40. 'Othering' is meant here in its common understanding within postcolonial study as the dialectical process of identifying an Other against the Self. For more on this, see Gayatri Spivak, 'Can the Subaltern Speak?', in Cary Nelson and Lawrence Grossberg (eds), Marxism and the Interpretation of Culture, Urbana, IL: University of Illinois Press, 1988, pp. 296-297. Here 'knowing' makes reference to Michel Foucault's pouvoir/savoir ('knowledge/power') paradigm; see M. Foucault, Knowledge/Power: Selected Interviews \& Other Writings, New York: Pantheon, 1980.

41. Brantlinger, Rule of Darkness: British Literature and Imperialism, 1830-1914, Ithaca and London: Cornell University Press, p. 144.

42. The reviewer includes gloating remarks about the irrationality of a female character in Hajji Baba as reminiscent of English girls 'in every boarding school for five miles around London'.

43. 'Hajji Baba of Ispahan', p. 51 (see note 10).

44. Ibid.: 52 .

45. Ibid.: 52 .

46. Ibid.: 53

47. Ibid.: $53-54$.

48. Ibid.: 52 .

49. Ibid.: 57, emphasis added.

50. A curious embellishment on the notion of 'the public' readership is hinted at in a letter from Morier to James Murray, his publisher, in negotiations for the terms of the publication of his work Zohrab, the Hostage. Apparently, after showing a manuscript of the work to Frances Burney, and having met with her approval, Morier asked Murray to consider the fact that Burney is an author herself and likely to know the tastes of her sex \& as they will form the greater part of my readers I think her approbation valuable' (quoted in Henry McKenzie Johnston, Ottoman and Persian Odysseys: Fames Morier, Creator of Haji Baba of Ispahan, and His Brothers, London: British Academic Press, 1998, p. 218; emphasis added). Unfortunately, this paper cannot begin to tackle the complication this comment introduces to a notion of the 'reading public' that would consume books of the Oriental Tales genre in 1824.

51. 'Hajji Baba of Ispahan', p. 57.

52. Ibid.: 57.

53. Johnston, Ottoman and Persian Odysseys, p. 213.

54. James Justinian Morier, The Adventures of Haiji Baba of Ispahan, English Classics, Chicago, IL and London: Stone and Kimball Methuen and Co., 1895, p. ix.

55. Ibid.

56. See, for example, the memoir: Morteza Mushfiq Kāshān̄̄, Rūzigārhā va Andīshihhā, Tehran: Ibn Sinā, 1962, p. 59. In particular, Kashani describes the cultural scene in Iran in latter part of the second decade of the 20th century, which is to say, some 15 years later than Shaykh Ahmad's death. Yet we may imagine that this practice was established previously, with the constitutional revolutionera papers such as Akhtar. See also Āryānpūr, $A z$ Sabā Tā Nimāa, vol. 2, pp. 21-25. This text describes the manner in which expatriate publishers of reform literature such as pamphlets and newspapers would anonymously mail their publications to a wide variety of people, both sympathizers and not, in Iran through intermediary addresses in Paris or Berlin. 
57. Marāghih̄̄, Siyāhatnāmih-yi Ibrāhīm Bayk, Yā Balā-yi Ta'aaṣsub-i Ou, Tehran: Nashr-i Sepideh, 1988, p. 16.

58. Morier, The Adventures of Hajii Baba of Ispahan, p. 456.

59. As already noted, it is most likely that Mīrzā Habīb had obtained a copy of the 1824 translation by Defauconpret: James Justinian Morier, Hajji Baba, traduit de l'anglais par le traducteur des romans de sir Walter Scott, Auguste-Jean-Baptiste Defauconpret, Paris: Haut-Coeur et Gayet jeune, 1824.

60. See the discussions of Hajji Baba's translation in: Hasan Kamshad, Modern Persian Prose Literature, Cambridge: Cambridge University Press, 1966; and Hasan Javadi, Satire in Persian Literature, London: Associated University Presses, 1988.

61. Gianroberto Scarcia, 'Quel critère de choix dans la traduction Persane du Hajji Baba?', in T. Zarcone and F. Zarinebaf-Shahr (eds), Les Iraniens d'Istanbul, Istanbul-Téhéran: IFÉA/IFRI, 1993, pp. 187 191.

62. Edward W. Said, Orientalism, New York: Vintage Books, 1979, p. 193. 